\title{
Plasma Cell Leukemia in Remission
}

National Cancer Institute

\section{Source}

National Cancer Institute. Plasma Cell Leukemia in Remission. NCI Thesaurus. Code C3585.

History of plasmacytic leukemia after therapy with no evidence on the peripheral blood or bone marrow of leukemia (normalization of all hematologic parameters). 